\title{
Interreligious Education: Transnational and Trans- Spiritual Identity Formation in the Classroom
}

\author{
Christine J. Hong
}

\begin{abstract}
This chapter engages with ways interreligious and intercultural pedagogies might honor and make visible the religious and cultural diversity present in classrooms by co-cultivating new forms of trans-spiritualities and nurturing a commitment to mutual transformation. It examines how minoritized people and communities carry porous boundaries across space, time, and lands, creating new practices, customs, and lexicons, while simultaneously struggling with the impact of internalized cultural and religious hybridity. The chapter discusses the dangers of white and Christian supremacist understandings of non-white and non-Christian communities, and the resistance of such supremacism to any naturally hybrid and dynamic representations of culture and religion in the intercultural and interreligious classroom.
\end{abstract}

Stories are the cornerstone of how human beings learn in a vibrant and intersectional world. C.S. Song reflects on the power of story for theological and personal formation in his book, In the Beginning Were Stories Not Texts: Story Theology. Song asserts that story making and storytelling simultaneously deconstruct and construct the matrix of our theological commitments. It is in childhood that we start this process of inquiry: the deconstruction and construction of our understandings of one another and the world. From the moment we begin to point at objects, wondering what they are, we enter the process of inquiry, of learning how we are influenced by the actions of others, the push and pull of the world, and how our own embodied ways of being might help or harm those around us. As we continue to learn, our stories change with the continued deepening of our experiences of the world and one another. The alterations to our narratives are what help us learn and hear across human differences, especially different lived religious and spiritual 
commitments, the misunderstandings of which, at times, threaten to keep us fearful and separated from one another.

Our deep entanglement in story, particularly stories about religious and interreligious commitments, is what teaches us about others and ourselves. The process of investigating story, creating, sharing, telling, internalizing, and interpreting, helps us wrestle with the deep-seated fears, biases, and assumptions we may harbor towards others with whom we share this world. As we learn more about the ebb and flow of student formation in interreligious classrooms, particularly the identity and spiritual formation of students of color in North America, our pedagogies need to shift along with our students to center the power of these changing stories, both our own stories and the stories of the collective "we." This essay begins by describing the impact of story on the liminal transnational and trans-spiritual identity formation of students, and concludes by identifying ways this lens can impact classrooms and pedagogical approaches to student learning, particularly within intentionally intercultural and interreligious spaces. ${ }^{1}$

Story as Transnational and Trans-Spiritual Empowerment

The sharing of stories and narratives is part of how identities are formed, shaped, and reshaped. As a second generation Korean American, my identity and commitments grow increasingly transnational. The stories shared with me by the older immigrant generation reconnect me to the land that my parents left behind. The stories of a painful immigration, war, and refugee experiences of survival and thriving, have been transmitted, internalized, examined, written down and retold and continue to connect me to Korea and the Korean people, as well as to their collective histories and concerns. These stories also

1 I am using the term trans-spiritual to describe religious and spiritual commitments, beliefs, and practices that originate from different experiences, places, histories, and religious and spiritual traditions, but that are embodied and held together in one individual. Like transnationalism and its commitments, trans-spirituality does not merge, synthesize, or syncretize distinct commitments, but these commitments, practices, and beliefs exist, are present, and transformed in tension and conversation with one another. Trans-spirituality is not a cherrypicking of religious beliefs and practices, but rootedness in them through communal, familial, and personal histories, experiences, and commitments. Trans-spiritual practices, for persons and groups with colonized histories, can be practices that were once indigenous and that have been re-interpreted, and re-indigenized. 
connect me to the faith and spirituality that sustained them throughout painful periods of history.

Stories that emerge from lived experience make deep imprints on our consciousness and even our genetic data. Numerous studies of displaced communities, First Nations, Holocaust survivors, and African Americans reveal the extent of trauma's imprint on the DNA. The effects of trauma have deep psychological and physical ramifications for future generations, many of which have yet to be understood. Shared narratives across generations and the resulting ways in which we learn to carry those stories in and on our bodies and through our actions, affect us and the stories we tell. They connect us to spaces, places, and often indescribable emotions across oceans and time. Is it possible that it is not only trauma that imprints on us, but also the practices that sustain us or help us cultivate resilience in the face of traumatic experiences as well? Perhaps spiritual practices and the benefits we receive from them, and religiocultural identities also, are transmitted through collective experiences and the sharing of stories. If so, how might making space for understanding and cultivating transnational and trans-spiritual identity formation alter the way we construct interreligious classrooms and approach interreligious pedagogy?

Though I was born in Los Angeles, I have always felt a deep connection with my Korean roots. For me, the concept of home has always felt nebulous. Home is neither here in the United States, where I remain a perpetual foreigner, ${ }^{2}$ nor is it in South Korea where much of my family still resides. Home remains both places and neither place. Home is not only to do with geography or the physical rootedness of my feet, but is also where I feel the most present in my body and comfortable in my own skin, without feeling the need to constantly explain myself or the dynamics of my identity and commitments. This includes how I might or might not cultivate and practice my spiritual and religious beliefs. This transnational and trans-spiritual identity was partly facilitated by frequent travel to South Korea and our close-knit family systems.

Transnational and trans-spiritual identity formation is dynamic and constantly negotiated. The objects of negotiation include spiritual and religious identities, beliefs, and practices. As this negotiation occurs, internal and external third spaces are created. Levitt and Waters, in their edited volume on transnationalism among youth and young adults showcase several examples of the formation of transnational identities across newly malleable boundaries. Immigration no longer effects the permanent severing of familial or national

2 "Perpetual foreigner" refers to Asians and Asian Americans who because of the stereotypes and prejudices associated with their appearance cannot assimilate to North American life. They are assumed always to be foreign, visiting, or traveling through, but never at home. 
ties. Many second and third generation North Americans identify home as multiple places and people, not restricted to national boundaries. While their commitments to these different places, nations, and people can often conflict, they are still held together without the need to work out the conflictual commitments. ${ }^{3}$ For instance, as a child I remember a common question second-generation Korean Americans would ask one another: "If the United States and Korea ever went to war, which side would you be on?" It was one of those questions without an answer. While we were situated in the United States, with parents - the immigrant generation-having worked diligently to carve a path forward for us, many of us still had relatives in Korea whom we still visited. Complicating this was the cultural and Confucian values of family loyalty and honoring one's elders, and the ever-present racism and discrimination we experienced as perpetual foreigners in a white supremacist land.

In the interreligious and intercultural classroom that is intentionally porous and self-revelatory, I increasingly find students choosing to self-identify as transnational and increasingly negotiate their religion, spirituality, and faith in boundary-crossing ways. As students engage with and unpack their personal narratives, identities, and inheritances, they discover that their spiritual practices are rooted in more than one community and more than one location. I once had a student in a class on interreligious engagements in diaspora who at first identified as a Christian white male. As the class went on and we focused on what it meant to identify with our personal histories, he revealed to his colleagues that he actually identified as a Latinx man who had been raised both Catholic and Wiccan and who came to Protestantism later in life. He shared that he had initially chosen to identity as a white Christian male because he had learned that a fair-skinned and light-eyed Latinx man who practiced Protestant Christianity with Wiccan and Roman Catholic understandings and underpinnings was problematic for those he encountered. He learned to present himself as people expected him to be rather than explore who he knew himself to be in his innermost being. The white Christian male identity afforded him privilege and social capital, but made for a challenging personal and spiritual life.

Transnationalism and its defining characteristics can extend to the landscape of trans-spiritualism and one's inter-spiritual and interreligious commitments. Hybrid religious and spiritual practices become embodiments of negotiated transnationalism. My family has been Christian for three generations. Christianity and its practices took root while my grandparents were still in North Korea. As they embraced Christianity, and Presbyterianism in particular,

3 Peggy Levitt and Mary C. Waters, The Changing Face of Home: The Transnational Lives of the Second Generation (New York: Russell Sage Foundation, 2002). 
they put away the Confucian-cultural practices that for them could not be assimilated and reinterpreted into their new Christian theologies and beliefs. However, what is consciously buried does not always stay underground. As various historians, theologians, and scholars on Korean American religious practices began to uncover the indigenous origins of Korean Christian practice, ways of trans-spiritualism also began to emerge.

\subsection{Porous Boundaries}

One of our family's rejected practices was the practice of jeh-sah or ancestor veneration. Counter to what white European and North American missionaries assumed, the practice of jeh-sah is not one-dimensional ancestor worship. It is the practice of remembering the dead and the recognition that the boundaries of life and death remain porous. The living set a banquet table for the deceased, placing the dead person's picture on the table along with their favorite foods, and in contemporary practice, items that held meaning for that individual while they were alive. The living then bow before the table and offer prayers. These prayers are conversational, wishing the spirit well, asking for guidance and protection for the living. This practice of setting jeh-sah table and holding conversational prayer, articulate the permanence of a relationship that is not severed with death.

I started practicing jeh-sah on the first anniversary of my maternal grandmother's death. Even after her death, I still feel her presence deeply upon my life. At each anniversary I lay out the banquet table, including the handwritten Bible she gave me on the occasion of one of my last visits with her. This practice has helped me feel a profound connection, not only with her, but with my Christian understanding of the cloud of witnesses and the resurrected body, as well as with the indigenous shamanistic practices of the Korean people for the releasing of han or the collective suffering of the people. Transnationalism is for me also trans-spiritual and decolonial. I hold my commitments to the United States and the Korean Peninsula together with my commitments to Christianity and the spiritual practices of my people, which are now being reclaimed from their erasure during the encounter with Christian mission and Japanese annexation.

Over the years, other trans-spiritual practices among transnational immigrant communities have been assimilated and re-appropriated for the sake of new religious practices in a new land. The connective tissue of the land, culture, religions, and spiritualities left behind are re-cultivated for a new place to ensure the survival and thriving of the transplanted community. In their edited volume, Gatherings in Diaspora, Warner and Wittner describe the hybrid 
practices of Catholic Haitians in New York who practice elements of Santeria, as well as the religious and cultural adaptations made by Jewish Iranians in the Los Angeles area. ${ }^{4}$ In the Korean American community such hybrid practices are most prominently reflected in ttong-song-kido (fervent prayer) and early morning prayer, both which possibly originated out of very early Shamanistic practices of confronting and releasing han. ${ }^{5}$

This reinterpretation and transformation of embodied spiritualities and identities does not begin or end with immigration or migration. New converts to and from different religious traditions can also, intentionally and unintentionally, carry with them personally significant religious practices and theological understandings about G-d and self into sacred spaces. In our fluidity, we human beings bring forward our narratives, the histories, theologies, beliefs, and practices of our people into new religious and sacred spaces, particularly in moments of crisis. I was raised in a Presbyterian family and church, although one that practiced reformed traditions in decidedly Pentecostal and charismatic ways. This practice is not uncommon among new immigrant Christian communities in Asian America. ${ }^{6}$ To this day, even though I am an ordained Presbyterian minister committed to the theologies behind reformed spirituality and practice, when in crisis my prayers become decidedly Pentecostal and charismatic. When I need to expediently communicate with G-d, I do not go to a book of prayers or recite creeds. Instead, I pray spontaneously and unabashedly ask for the things I want and need, including the expectation of divine and miraculous intervention on my behalf. My reformed theology allows for spontaneous prayer, but would challenge the logic and ethics of petitioning of G-d in this manner. However, in crisis, my prayer practices organically overcome these boundaries. What is at the foundation of our spiritual formation cannot always be exorcised from us. I have observed this boundary crossing between religious and spiritual practices in the lives of others as well. Once, at a biennial gathering of Presbyterians, an interreligious guest received communion at our Assembly-wide service. A practicing African American Muslim who converted in early adulthood, she cited her deep belief in the connective quality of the Christian sacrament of communion for both people and

4 R. Stephen Warner and Judith G. Wittner, Gatherings in Diaspora: Religious Communities and the New Immigration (Philadelphia: Temple University Press, 1998).

5 Han is the indigenous Korean terminology for collective sorrow, grief, and pain. Han can be personal, connectional, and national. Practices of prayer like ttong-song-kido can in effect be a cry of lament and releasing of han.

6 Charismatic practices among Korean American Mainline Protestant Christians echo the indigenous shamanistic roots of Korean spiritualities. 
the divine as her reason for participation. This most likely went against both our traditional and theological preconceptions, but she was embodying her trans-spiritual and communal commitments in a way that made sense for her religious and spiritual life journey, the places from whence she came and the new places her religious identity locate her today. As I watched her receive the bread and the wine, the body and blood of Christ, she was in my view crossing back and forth between the same porous boundaries that separate me from my grandmother at the jeh-sah table.

\section{$2.2 \quad$ Technology}

These porous boundaries between national, spiritual, and religious spaces and practices are further facilitated by evolving technology, which in turn changes the way students engage with one another and the world in the interreligious classroom. When my parents emigrated to the United States, they lost the ability to have instantaneous communication with their loved ones. Long distance calls were too costly other than for emergencies and special occasions. Letters had to be handwritten and took weeks to arrive. The feeling of loss and separation was much more permanent than it is now. Today, technology allows transnational peoples to engage with their different homelands in a multiplicity of ways and in real time. ${ }^{7}$ People are able to experience rootedness and commitments to other places and people via technology. They are even able to observe and participate in worship with communities across the world. Through the power of technology, we are no longer bound to a single location. With the help of technology, interreligious classrooms become interreligious spaces across national and spiritual boundaries through the observation of worship in different places around the world, and the direct engagement with different religious practitioners via video conferencing. Students are no longer bound by texts on paper; instead people all over the world become living texts through which students are able to learn. As transnational religious and spiritual people, we are also no longer bound only to mine and interpret our historical stories to ground and develop our current theologies and spiritual practices. We are able to make meaning and create new stories with living communities and living practices, by cultivating of newly-formed spiritualities together. We are able to follow diverse stories and curate our identities and commitments through encounter with the identities and commitments of others as they happen.

7 Levitt and Waters, The Changing Face of Home. 


\section{Cultivation of Trans-spiritual and Transnational Identities and Narratives}

While technologically-transmitted narratives, because they are living texts, sustain the porous quality of inter-spiritual boundaries in interreligious education, they are also susceptible to dangerous romanticizing. The construct of "home" is created and re-created through technologically-transmitted narratives that can be romanticized into re-imagined communities and renewed meaning making around spiritual practices. Confucian practitioners, Korean American Christians, and even members of my own family would most likely profess shock at my practice of jeh-sah for my grandmother. Truth be told, perhaps part of my impetus in resurrecting the practice of jeh-sah may be the way I have romanticized some of the narratives that have been passed down to me from those of my parents' and grandparents' generation. South Korea and all she possesses is irreplaceable in my mind's eye. She is flawed but not irredeemably so. My cousins, Korean nationals, on the other hand, are always surprised by how much I long for "home" and how much I dread leaving when I visit. I always cry upon departure; it is a keening of loss, the loss of the warm feeling of comfort, of the feeling of belonging that can only come with hearing your mother tongue all around you and living in a context that does not require you to explain yourself at every turn. Perhaps it is a loss that is partially my own romanticizing of homeland. I will continually remake my trans-spiritual practices based on how Korea continues to transform herself in my heart and mind. Unfortunately, this transformation can lead to the erasure of other conflicting but significant narratives.

Why the need for rose-colored glasses? Are we looking for a blanket positivism to cover over the narratives we would rather not immerse ourselves in? There are dangers to this cultivated and romanticized form of transnationality and trans-spirituality. The rose-colored transnationalities and transspiritualities and the curation of the narratives we receive can render invisible entire narratives and histories, including the most painful and unspeakable stories. We risk the danger of curating privileged narratives that avoid the sticky and messy stories we hesitate to hear and re-tell. Romanticizing our transnational and trans-spiritual identities can encourage us to see only what we desire to see and little else. Students and instructors are at risk of picking and choosing what is most meaningful to them, centering their own stories without consideration for the larger narratives and the stories of others from which their own emerge.

In the face of self-cultivated identities and commitments, how do we continue to foster a type of interreligious education that encourages students to 
take off their rose-tinted glasses? How do we help students work through the process of holding disparate narratives together for the purpose of a more holistic and communal identity formation? JoAnn D'Alisera documents the differing narratives of Sierra Leonean families in the Washington DC area: ${ }^{8}$ While the second generation, through the narratives heard in the media and public education system, imagines "the dark heart of Africa" and all that this bias implies, their refugee parents describe rich and beautiful histories, lands, and cultures that were left behind for a hostile North America. These youths hold these two disparate narratives together in tension, wrestling with what these conflicting stories might mean for them and their commitments to both the United States and Sierra Leonean communities at large. What are our students learning about their constantly curated identities and stories in the classroom? Is what they are learning in the classroom porous enough to enable them make sense of, and create room for alternative narratives they will encounter of other places, people and experiences at home, in worshipping communities, and in the media?

In the interreligious and intercultural classroom, there must be an intentional balancing of the narratives that are transparent and the narratives that are hidden, as well as an uncovering of the way narratives are destroyed and altered, particularly through the white and colonist gaze. This is especially the case for people in the diaspora who learn about their motherlands in spite of a lack of information about them in our textbooks, or do so through the lenses of the conqueror over the conquered and the civilized over the savage. The classroom must equip students to hold these divergent stories in tension, help them sift through and critically and powerfully examine, deconstruct and reconstruct the stories they encounter.

As the second and third generations receive stories from the immigrant generation, unpack them, and make new meaning from them, including the creation of hybrid spiritual practices, they also hear and internalize a different set of narratives from a white supremacist culture and its accompanying white gaze on "foreign" histories, religious practices, and peoples. During a conversation with my family in Korea early in my adolescence, I was astounded to discover that the narrative of the American military as "savior" post Korean-War was not the narrative my family understood. Their understanding was of American military occupation on South Korean soil, an occupation that was

8 JoAnn D'Alisera, "Images of a Wounded Homeland: Sierra Leonian Children and the New Heart of Darkness," in Nancy Foner, ed., Across Generations: Immigrant Families in America (New York: New York University Press, 2009), 114-34. 
tolerated because of the nuclear threat of North Korea, but not welcome because of the violence from American soldiers, the embedded American exceptionalism, and the neocolonial white supremacist lens that came with American military presence on Korean soil.

As the studies in intergenerational trauma mentioned earlier reveal, there are continuing effects of empire and colonial histories on the transnational identities of people of color in the United States, including the ways the white gaze and American exceptionalism have bled into the narratives we have interpreted and internalized about our homelands. This reality and tension leads to a continuous process of unpacking and reimagining our identities and the spiritual and religious practices embedded within them. Just as I have done with the jeh-sah practice, there is a movement by those with colonized histories in North America to reclaim and reimagine the spiritual practices that have been lost or erased through encounters with Christian mission and other forms of imperialism. However, this reclamation can cause individuals to feel simultaneously empowered and isolated in their respective chosen communities, therefore necessitating a re-negotiation, not only of religious and spiritual belief and practice, but also of the relationship between community and personal identity. My status as an ordained clergy person both empowers me in religious spaces and makes me into a disorienting agent for many in the Korean American community. As a result I feel largely isolated from those in the Korean American community who adhere to more conservative theologies around women's ordination. I embody a negotiation of stories and their meanings remade. My very presence as a woman with spiritual and religious authority is a challenge to the norming of Confucian-Christian practices that ally maleness with holiness. Simply by dwelling in this tension within the community creates a necessary conflict and conversation, which heads towards transformation and newly-negotiated spaces that disrupt paradigms of power and privilege in Korean American congregational life and theology. This in turn deconstructs the overlay of white-Christian supremacist narratives that seek to simplify Korean culture by representing it as rigid, theologically conservative, and sexist.

\section{Rethinking Pedagogical Approaches in Interreligious Education}

With these complexities in mind, how do we approach interreligious and intercultural classrooms, where many of our students are nurturing transnational and trans-spiritual identities? First, I define interreligious classrooms and 
interreligious education as spaces where participants are intentionally learning and negotiating the complexities of interreligious life, as well as the larger systemic and societal structures of public and religious life. Part of the process of interreligious education and learning is to remain open to one another's particular cultures and traditions for the sake of appreciation, without the need for proselytization. How do we encourage students to retain these porous boundaries between one another's narratives and histories in their cultivation of identity through story, all the while retaining a sense of self-esteem and growing their capacity to courageously engage with the tensions and conflicts they are bound to encounter? What are some practices that will ensure students' identities are not subjected to a secondary erasure by the colonist and white gaze, or to destructive forms of assimilation through the parameters and measures of success and failure set by western forms of theological education?

\subsection{Conflict in the Interreligious Classroom}

Conflict in the classroom, especially around negotiated identities, is not something we should fear. In his text, Transformative Classroom Management, John Shindler frames conflict as a way forward, a way to co-create a culture of listening and respect. Conflict in the classroom, when surfaced and properly engaged with, can open doors to new ways of hearing one another. ${ }^{9}$ Though Shindler is referring mostly to classrooms of adolescents, his theory is applicable in interreligious spaces as well. If adolescence is a heightened time when our identities are tested and selfhood is learned, interreligious and intercultural spaces in theological education are heightened times of formation for classroom participants also, particularly for white Christians who have never before had the primacy of their religious or cultural identities challenged in North American spaces.

Often when conflicts arise around contested religious and cultural identities, stories, and perspectives in the classroom, our instinct is to quickly and efficiently re-direct or diffuse the topic. Yet when we follow this instinct, what is really challenged and changed in the identities and perspectives of the instructors and students? Perhaps only the authority of the instructor is reaffirmed. When properly and carefully mediated, conflicts can become vehicles of community and individual transformation for both the instructor and student and by association, adjacent communities. The students' very presence, as they embody the transnational and trans-spiritual identities they are

9 John Shindler, Transformative Classroom Management: Positive Strategies to Engage All Students and Promote a Psychology of Success (San Francisco: Jossey-Bass, 2009). 
constantly re-negotiating, transforms and challenges the classroom space. Classmates and instructors learn from these students' perspectives and stories and from the lenses they use to interpret and curate the narratives, identities, and spaces they call home. By lifting up and uncovering what is already being embodied in our students, our understandings of identity and spiritual formation become porous together, making learning across difference much more possible and collectively transformative, effectively extending the classroom towards inward spaces of learning and beyond physical walls.

As potentially transformative as conflict can be when encountered strategically in the classroom, instructors must first establish classrooms that are hospitable to both the transnational and trans-spiritual identity formation of students and instructors. Conflicts in the classroom can arise as consequences of classrooms being unintentionally inhospitable places for the negotiation of these fluid identities, and instead being places that assume that identities are rigid and that the performance of identities is as deep as identity goes. ${ }^{10}$

\subsection{Presumed Identities}

When instructors and students assume identities in the classroom without taking the time to leave the borders around identities and identity performance porous and open, key identity markers that are being constantly and tenuously negotiated remain invisible. This invisibility can occur through micro-aggression by both students and teachers. Common experiences include assumptions about social location and socio-economic status, the mispronunciation of ethnic names, and the rendering invisible of disabilities. Recent studies have shown the negative effect on students of color when their teachers and others mispronounce their names in public spaces without correction. Entire histories and the meanings that are embedded when names are created and given become invisible and are rendered powerless. ${ }^{11}$ Studies of Asian American children and adolescents further reveal that this powerless feeling extends to the formation of the person's self-esteem and can even result in self-harming behaviors. ${ }^{12}$

10 Judith Butler notes that gender is performed and essentially fluid outside of societallyconstructed performativity. I am asserting that national, racial, ethnic, religious, and spiritual identities are also fluid, but that students and instructors learn to perform out of more rigid societal expectations of identity, and out of necessity and survival in inhospitable environs.

11 Corey Mitchell, "A Teacher Mispronouncing a Student's Name can Have a Lasting Impact," PBS, May 16, 2016, accessed September 8, 2016, http://www.pbs.org/newshour/rundown/ a-teacher-mispronouncing-a-students-name-can-have-a-lasting-impact/.

12 Nita Tewari and Alvin Alvarez, Asian American Psychology: Current Perspectives (New York: Psychology Press, 2008). 
When an instructor's lenses are not sufficiently self-reflective or examined for bias, presenting identities in the classroom tend to be privileged over those whose identities are more internalized, but just as, if not more tangible, for the people who hold them. In the classroom, this can take the form of Christian privilege or the privileging of Christian narratives and persons, clergy privilege, heteronormativity, male privilege, or the centering of the white gaze and white privilege. Subjection to such privileging can also be the experience of instructors of color in the context of Western institutions and training. ${ }^{13}$

Classroom environments and the pedagogy we use within them should work to encourage the deepening of self-identification over assumptions, as well as the simultaneous self-interpretation of multiple identities, including those that are religious, spiritual, national, etc. Good pedagogical practices work to unpack how student, teacher, and community identities are negotiated and understood, and they lift meaning out of even the seemingly smallest of identity markers. G. Yamazawa, a Japanese American artist of the spoken word, describes the power of his father's accent in his poem The Bridge: "My father's accent is like climbing a barbed wire fence ... it means he spent more time cooking for other people in his restaurant making ends meet for his family than trying to learn English." More than a marker of immigration, for Yamazawa, his father's accent told of his father's commitments, choices, and even love for his family. What would our classrooms look and feel like if instead of only learning how to pronounce one another's names correctly, we also encouraged the unpacking of our names? If we asked how names were born and how we received them, what they meant to the giver and what they mean to us? How they continue to shape us? Sometimes our motherland names are the only link some of us have left to the mother tongue or our homelands.

My grandfather gave me the Korean name Hong Jin. In the Chinese characters that it comes from Hong means wide while Jin means small and precious. To my grandfather, I was a small and precious person across the wide expanse of the ocean he was waiting to meet. I cannot think about my given Korean name without thinking of this story, the origin of my name, the person who gave it to me, and the deep longing and sorrow he must have felt at not being able to meet his first grandchild until much later. Just as names have deep rootedness in how our identities are shaped and how our transnational ties are carried and sustained, spiritualities and spiritual practices are

\footnotetext{
13 Indigenous scholars like Linda Tuhiwai Smith and Andrea Smith reflect on the decolonizing of the indigenous scholar's mind from the influence of Western epistemologies and research processes.
} 
also inheritances and legacies that connect us to our many "homes" within the classroom space.

\subsection{Christian and White Privilege in Interreligious Education}

Interreligious education seeks to identify and interrogate the pervasive Christian and white privilege in interreligious and intercultural life. Even when homogeneity appears to exist, for instance in an entirely Christian or an entirely Muslim classroom, deep differences do exist and need the appropriate spaces to present themselves. In an essentialist North American culture, many of our differences necessarily become submerged within the larger umbrella of racial identities and commitments. Entire communities have undergone this submersion in order to survive within the hostile white supremacist systems and Christian privileging that occurs in North American society. However, when this categorization becomes the primary and only mode of cultivating identity in the classroom and other systems, the deep conflicts embedded within even large identifying umbrellas become buried. For instance, the complex and unique ethnic Asian and Asian American histories become invisible in lieu of an essentialist and often East Asian oriented narrative of Asian America. Contrary to the belief that all colonists were white Americans and Europeans, Asian history is full of colonial histories, occupations, oppressions, and liminalities that occurred solely among and between Asian nations and peoples. In the U.S. context, this call to assimilation, to melt and become singularly Asian American also extends by default to our religious narratives and identities in the social and American public sphere. Even among students who identify with the same signifiers will understand those signifiers differently. For instance, Christianity, its lived theologies, and practices mean different things to Christians everywhere. The 2014 gathering of the ecumenical World Council of Churches in Busan, South Korea, was heavily boycotted outside by none other than Korean Christians who did not agree with the ecumenical practices the wCC pursued. In the same way, being "Asian American" means different things to different Asian Americans, whose immigration histories, points of arrival, and participation in American civic life are vastly divergent. We can say the same for people who affiliate and identity as either Hispanic, Chicano, Latin@, or Latinx but whom the census would like to identity as one singular category: Non-white Hispanic. Like racial and ethnic identity, religion and religious experience is multifaceted and never monolithic. When teaching and learning in the porous classroom, we resist the urge to pin down one normative meaning or experience, and when we must adopt essentialisms, we do so in the acknowledgement that this move towards normativity always frames 
outside experiences as marginal and irreconcilable with a privileged central narrative.

Like our constantly negotiated identities, hybrid spiritualities and practices in the student and in the classroom are always shifting. These moves are influenced by various factors, including the classroom makeup, home, worship spaces, etc. These changes are deepened through encounters with others in a constantly changing community. A helpful pedagogical approach works to lift up the dynamic nature of communities and classrooms, not as things to be essentialized, or in some cases, newly colonized, through one monolithic interpretation, but held in tension with one another. The conflicting narratives in a classroom need not always agree with one another, but can sit together in tension, creating a space where each participant feels camaraderie over the level of risk involved in continually negotiating identity and spirituality. Therefore, pedagogical approaches in intentionally interreligious and intercultural spaces should validate and affirm the existence of trans-spiritualities and continually complex identities, with the experience of tension held up as the catalyst for mutuality. This comes from our understanding of religious and spiritual dynamism as more than a patchwork of religious practices and beliefs. Our resistance to understanding some world religions as hybrid realities can be broken down when we begin to understand that some of our religions, including Christianity, have been hybrid realities from inception. ${ }^{14}$ Trans-spiritualities and practices can exist in seemingly mono-religious spaces and identities. As mentioned earlier, hybridity is a cornerstone of many seemingly monolithic Christian practices, particularly in immigrant and migrant Christian communities. These tensions need to breathe and they bear exploring in the classroom. Even the tension between religion and spirituality-the assumption of one being more valid than the other-is a nebulous space we can explore in interreligious education.

\subsection{Hospitable Interreligious Classrooms}

Hospitable interreligious classrooms facilitate the co-formation of identities and spiritualities and render complex the relationship between them. Students, teachers, and educational institutions are shaped and reshaped in their encounters with one another-in joy, grief, conflict, and creation. For the practical theologian in particular, the goal of any rigor within the classroom is transformation of the participant, institution, and society..$^{15}$ Practically, this

\footnotetext{
14 Paul Bradshaw and Maxwell E. Johnson, The Origins of Feasts and Seasons in Early Christianity (Collegeville, MN: Pueblo Books, 2011).

15 Richard Osmer, Practical Theology: An Introduction (Grand Rapids, MI: Eerdmans, 2008).
} 
mutual transformation can occur with the perpetual asking of the question, "Who are we?" and close examination of how we draw lines around the "we." For instance, whose interests are served in the boundaries we draw around "we"? Who is permitted to draw the lines? Who is excluded? Who benefits from the "we" that is established and who is minoritized?

Amos Yong expands the notion of "we" in Christian theology to include those of other religious traditions. Yong, a Pentecostal theologian who specializes in pneumatology for interreligious engagement and life, identifies radical interreligious hospitality as a function of the Spirit of G-d. Yong postulates that, for Christians, even in the Spirit's function of evangelization, there is a strong element of attitudinal conversion and re-conversion to one's own doctrines of neighborliness and hospitality that is required for deep engagement with and commitment to Christian life. ${ }^{16}$ If we follow Yong's understanding of we-ness, interreligious education is a way in which, by deeply embodying radical hospitality towards one another, by opening ourselves up and deepening our appreciation of difference, we become truer adherents of the religious traditions and cultures that we claim.

The porous classroom, like our porous identities and spiritualities, requires the understanding that learning and formation of religious and spiritual identity continues outside of the classroom space and deeply dynamizes the classroom experience. The classroom is porous and borderless in the sense that interreligious or interfaith dialogue and life is not only shaped with words but also through the art, music, silence, taste, communal memories, etc. that occur outside the classroom context; the experience of which only enhances how we navigate our interactions with others within the classroom space.

Pedagogy for the porous classroom, or a classroom that fosters hospitable spaces for the shifting identities and spiritual formation of students and teachers, constantly lifts up and tracks the varied dimensions of power and privilege in the classroom, and tracks how they change or are changed through encounters. ${ }^{17}$ Some of the markers of difference within structures of power and privilege include religion, gender, nationality, language, age, and sexuality. As facilitators of these spaces, we try and do this with care, through understanding and working with the vulnerable experiences of tracking identity formation through self-reflexivity in marginal spaces. Practical ways we do this include doing away with the false notion of "safe spaces" and moving into emboldened

16 Amos Yong, The Missiological Spirit: Christian Mission Theology in the Third Millennium Global Context (Eugene, OR: Cascade Books, 2014), 55-63.

17 Sheryl Kujawa-Holbrook. God Beyond Borders: Interreligious Learning Among Faith Communities (Eugene, OR: Pickwick Publishing, 2014). 
and democratic spaces. There are some people who are never fully safe regardless of where they are in society. Some people are always on the defensive because of safety concerns, having to explain themselves, or intentionally hiding aspects of their identities in order to survive. The reality is, to call a space "safe" in North American society privileges heteronormativity, men, able-ism, and whiteness. Individual and communal identities, religious and otherwise, can hold power in one space, but remain liminal in others. As previously described, my clergywoman status is empowering within my ecclesial family. The Presbyterian Church (U.S.A.) is currently 92 percent white, but my clergy status and denominational leadership give me access to transformative avenues of conversation. In my Korean American context, I am a paradox. A woman with spiritual and religious authority is perceived with suspicion as subverting normative Confucian structures and systems that are still deeply patriarchal.

\subsection{Dismantling Binaries and Assumptions in the Classroom}

We further the aim for hospitable interreligious education and classrooms by integrating anti-racist and anti-supersessionist approaches and critiques into our pedagogy and posture. As we work to lift up the dynamics of tension between narratives and make visible the stories, realities, and histories that have been buried through the centering of colonial narratives, we must also work to deconstruct dangerous binaries. The two most common binaries that work against the cultivation of holistic identities are the racial binary of Black and white and the religious binary of Christian and other. The Black/white binary works to suppress the complex narratives of people of color communities, while the Christian and other binary centers the Christian agenda and story over and against the rich diversity of religious and spiritual narratives in our world. We cannot hope to maintain the porous boundaries between transnational and trans-spiritual identities and practices within binary constructs that work to keep the complexities of different identities and commitments hidden and ultimately pit vulnerable communities against one another.

Other constructed assumptions that do not foster the complexities of identity and story co-forming in the classroom are generational and vocational assumptions. In theological education particularly, we can no longer assume that our students hail from a monolithic millennial generation with all the pigeonholed stereotypes this label carries with it. Assumptions about generational belonging damage the porous identities and borders we encourage in interreligious education. Generational assumptions work against potential intergenerational cooperation between traditions, cultures, and peoples. Today, it is 
common in theological education to have students from millennial, generation $\mathrm{x}$, and boomer generations sharing space and learning together.

Another intersection where assumptions abound is around vocational differences. Second and third career students share spaces with students with multi-vocational realities on the horizon. Many community religious institutions, such as churches and synagogues, can no longer sustain full-time staff and leadership. This shortage of traditional religious leadership roles has forced students in theological education to harness their creativity, patching together different leadership roles simultaneously along their career paths. The bringing together of second and third career students with students who will eventually need to be experimental to ensure income security, brings to light socio-economic disparities that in turn affect the different narratives in the classroom. In addition, the growth of non-traditional master's programs within the Association of Theological Schools reveals that students are entering theological education for reasons other than embarking on religious leadership. ${ }^{18}$ As instructors, how are we accommodating the different reasons students seek theological education, layered as these differences are with the different textures of their transnational and trans-spiritual commitments and formation, and their socio-economic and potential career realities?

Students bring their different lived experiences, histories, perspectives, generational and intergenerational gaps and realities, community and group resources, points of access, and communication styles into one collective space. This deep diversity may seem daunting at first because of the potential for conflict and misunderstanding. However, the gathering of these divergent narratives becomes less resistant to transformation when they are in co-formation together. In the presence of profound differences, student and instructor assumptions wear down and the boundaries between self and other become porous in the same way as our transnational and trans-spiritual identities and practices. It is possible that because of growing generational differences, and differences in social location in our classrooms of theological education, we are poised, more than ever before, to cultivate an increasing capacity for conversation about and through difference, which in turn supports the formation of students with transnational and trans-spiritual identities and commitments.

18 Association of Theological Schools, "Annual Data Tables, 2015-2016," accessed September 15, 2017, http://www.ats.edu/uploads/resources/institutional-data/annual-data-tables/ 2015-2016-annual-data-tables.pdf. 
The stories we hear, learn, and share shape us and those around us. Our stories are constantly shifting. They speak of our deepest commitmentstransnational and trans-spiritual—even those commitments that we are still learning to understand and unpack. They flesh out our religious beliefs and practices, both personal and communal. Our identities are threaded through with narratives that are simultaneously fragile and resilient, narratives that work against one another and exist in tension within the confines of our bodies and minds. Our identities, both transnational and trans-spiritual, are coformed in our encounters with one another, in particular in the intentionally vulnerable spaces of theological education.

Good and transformative pedagogy builds bridges between diverse stories, our histories, social locations, and understandings of religion and practices, without requiring students to assemble rigid and permanent definitions of self. It fosters classrooms that are hospitable and individuals who hold their identities, commitments, and practices in porous ways, so as to allow for the continual formation of selfhood that comes from the encounter with others. The way we nurture hospitable classrooms can encourage the breakdown of dangerous binaries and assumptions that promote hostility and fear, while encouraging mutual transformation towards one another. We ensure mutuality in thriving when we learn to hold the narratives, commitments, and practices in tension, both within ourselves and within spaces of learning.

\section{Bibliography}

Bradshaw, Paul and Maxwell E. Johnson. The Origins of Feasts and Seasons in Early Christianity. Collegeville, MN: Pueblo Books, 2011.

D'Alisera, JoAnn. "Images of a Wounded Homeland: Sierra Leonian Children and the New Heart of Darkness." In Nancy Foner, ed., Across Generations: Immigrant Families in America, 114-34. New York: New York University Press, 2009.

Kujawa-Holbrook, Sheryl. God Beyond Borders: Interreligious Learning Among Faith Communities. Eugene, OR: Pickwick Publishing, 2014.

Levitt, Peggy and Mary C. Waters, The Changing Face of Home: The Transnational Lives of the Second Generation. New York: Russell Sage Foundation, 2002.

Mitchell, Corey. "A Teacher Mispronouncing a Student's Name can have a Lasting Impact." Public Broadcasting Service. Accessed September 8, 2019. http://www.pbs .org/newshour/rundown/a-teacher-mispronouncing-a-students-name-can-have-alasting-impact/. 
Osmer, Richard. Practical Theology: An Introduction. Grand Rapids, MI: Eerdmans, 2008.

Shindler, John. Transformative Classroom Management: Positive Strategies to Engage All Students and Promote a Psychology of Success. San Francisco: Jossey-Bass, 2009.

Tewari, Nita and Alvin Alvarez. Asian American Psychology: Current Perspectives. New York: Psychology Press, 2008.

Warner, R. Stephen and Judith G. Wittner. Gatherings in Diaspora: Religious Communities and the New Immigration. Philadelphia: Temple University Press, 1998.

Yong, Amos. The Missiological Spirit: Christian Mission Theology in the Third Millennium Global Context. Eugene, OR: Cascade Books, 2014. 